UDC: 376.1-056.264-053.2; 616.22-008.5-053.2; 81'234-053.2

\title{
RETENTION OF AN IRREGULAR FEATURE SPECIFICATION AS A SOURCE OF FUNCTIONAL MISARTICULATION
}

ISAO UEDA ${ }^{1}$

Osaka University,

Graduate School of Language and Culture, Osaka, Japan

Ovo istraživanje predstavlja pokušaj analize fonološkog sistema jednog deteta, izvornog govornika japanskog jezika, koje ima vrlo specifičan funkcionalni (neorganski) poremećaj govora u kome se labijalizovani vokal zadnjeg reda uvek zamenjuje bilabijalnim nazalom. Najpre analiziramo odlike ta dva segmenta i primećujemo da oni dele fonološko obeležje [labijalan] u hijerarhijskoj organizaciji distinktivnih obeležja. Fokusirajući se na obrazac zamene i njene teorijske posledice u okviru teorije optimalnosti, razmatramo hipotezu da je ograničenje markiranosti koje u dečjem sistemu sprečava labijalizovani vokal višeg ranga od ograničenja vernosti, usled čega dolazi do zamene ciljanog vokala labijalnim nazalom. Zamena je izazvana pogrešnom specifikacijom pomenutih obeležja. Takođe iznosimo tvrdnju da održavanje takvog rangiranja ograničenja rezultira stvaranjem nedozvoljenih prozodijskih struktura, pored greške u produkciji samog segmenta. Najzad, primećujemo da je održavanje takvih nepravilnih specifikacija obeležja pri fonološkom razvoju česta pojava u jezicima, kao i da može biti jedan od izvora funkcionalnih poremećaja u izgovoru.

Ključne reči: fonološki razvoj, govorni poremećaj, funkcionalna misartikulacija, geometrija obeležja, teorija optimalnosti.

\section{INTRODUCTION}

The present study reports and discusses a very unusual case of functional speech disorder of a four-year-old Japanese-speaking child. Notwithstanding a widespread understanding that vowel disorders are rare in Japanese, this child exhibits a constant substitution in the production of the vowel $/ 0 /$, and the substitution pattern per se is very uncommon. The structure of this study is organized as follows. First we observe

1 Kontakt podaci (Email): uedais@lang.osaka-u.ac.jp 
the deviant articulation of the child, focusing on the substitution pattern. Second, a phonetic and phonological characterization of the child's system is laid out, with reference to Japanese phonology where necessary. Third, to explicate the cause of misarticulation an 0ptimality-Theoretic analysis is proposed. Finally, this case is characterized in connection with phonological development and functional speech disorders in general, with the conclusion that this is not really an idiosyncratic case and that the misarticulation can be deduced in the light of general principles of phonological theory and phonological development.

\section{UNUSUAL SUBSTITUTION BY THE SUBJECT}

The subject of this study is T.A., aged four, who exhibited constant substitution errors in production. ${ }^{2}$ This problem was diagnosed as functional misarticulation. Let us look at some examples in (1). Here, the child's actual production and corresponding ambient correct forms are labelled as phonetic forms and target forms respectively, and a syllable boundary is marked with a dot [ . ].

(1) Substitution errors of T.A.

$\begin{array}{lll}\text { Phonetic forms } & \text { Target forms } & \text { Gloss } \\ \text { tm.ra } & \text { to.ra } & \text { tiger } \\ \text { ni.ua.tm.ri } & \text { ni.ua.to.ri } & \text { chicken } \\ \text { a.sa.ya.m } & \text { a.sa.na.o } & \text { morning glory } \\ \text { ta.km } & \text { ta.ko } & \text { octopus } \\ \text { m.ka.san } & \text { o.ka.san } & \text { mother }\end{array}$

It is observable from this that the target vowel /o/ is being replaced by bilabial nasal $[\mathrm{m}]$. This case should be a focus of special attention because Japanese vowels are claimed to be acquired without causing any problems (Ito 1990). In fact, Homma (2000) asserts that unlike dysarthria, vowel disorders are not observed in functional misarticulation. In addition, Japanese has a relatively simple vowel system outlined below, which makes acquisition easier.

(2) Japanese vowel system

[i ]: front, high, unrounded

[ e ]: front, mid, unrounded

[ a ]: central, low, unrounded

[ o ]: back, mid, rounded

[ u ]: back, high, unrounded

Next, let us take a look at target $/ \mathrm{m} /$ to see if the child has a problem with the nasal itself. In (3) below, some production forms are listed.

2 The data were elicited at Osaka City Rehabilitation Training Center. I wish to thank Keiko Satomi for the contribution of the data herein. 
(3) Production of target [m]

$\begin{array}{lll}\text { Phonetic forms } & \text { Target forms } & \text { Gloss } \\ \text { me.na.ne } & \text { me.na.ne } & \text { eyeglasses } \\ \text { ja.ma } & \text { ja.ma } & \text { mountain } \\ \text { ka.ta.tsu.mu.ri } & \text { ka.ta.tsu.mu.ri } & \text { snail } \\ \text { hi.ma.ua.ri } & \text { hi.ma.ua.ri } & \text { sunflower } \\ \text { em.pi.tsu } & \text { em.pi.tsu } & \text { pencil }\end{array}$

The phonetic forms in (3) show that they are correctly produced. Note that in the last example [em.pi.tsu] "pencil", the syllable-final target is underlyingly an underspecified nasal without place specification; if it is in word-medial position, the "placeless" nasal surfaces assimilating to the following consonant. ${ }^{3}$ The child does produce the correct form. This and other forms evidence that target $/ \mathrm{m} /$ is properly acquired. So far, we have seen that the target vowel /o/ is replaced by $[\mathrm{m}]$, while target $/ \mathrm{m} /$, whether it is an onset or a coda of a syllable, is realized as such.

\section{THE SUBSTITUTED NASAL AND THE SYLLABLE}

In this section, we will examine how the substituted nasal behaves in syllable structure. It should be noted in (1) that this substitution happens even though it results in violation of $\mathrm{CV}$ which is the most unmarked syllable structure in Japanese. Let us see this anomaly in (4), in which the phonetic and the target forms of "tiger" are juxtaposed.

(4) The syllable structure of "tiger"
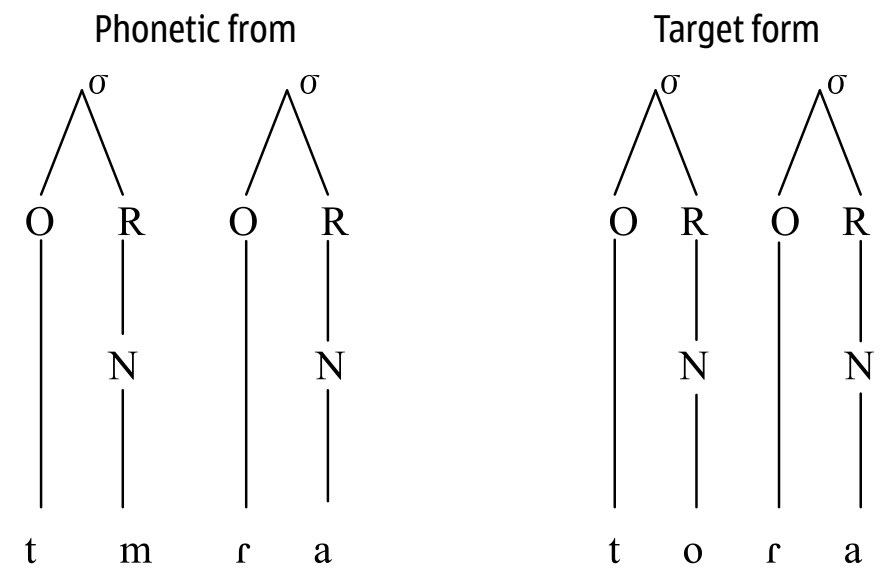

It is evident that the nasal functions as the nucleus of the syllable, which is not permitted at all in Japanese phonology. We now go on to see how the nasal works in more complex syllable structures. Specifically they are (C)V: and (C)VC as shown in

3 Note that the surface allophones of this placeless nasal are the only permitted forms in word-final position in Japanese. 
(5), the latter of which has already been touched on above in connection with the assimilation of the placeless nasal.

(5) The syllable structure of $\mathrm{CV}$ : and CVC

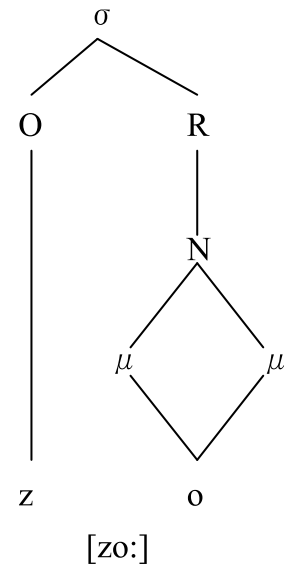

(elephant)

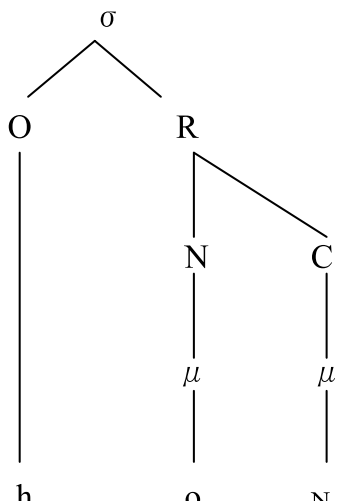

[hoN]

(book)

Now, let us look at some forms having either of these structures.

(6) Forms with a long vowel or with a coda nasal

$\begin{array}{lll}\text { Phonetic forms } & \text { Target forms } & \text { Gloss } \\ \text { m.tm:.san } & \text { o.to:.san } & \text { father } \\ \text { tan.m:.bi } & \text { tan.3o:.bi } & \text { birthday } \\ \text { m:.tfi.en } & \text { jo:.tfi.en } & \text { kindergarden } \\ \text { rai.m: } & \text { rai.on } & \text { lion } \\ \text { ku.re.m: } & \text { ku.re.jon } & \text { crayon }\end{array}$

The first three forms have a long vowel /o:/ in the target, giving a CV: structure, while the next two forms have /oN/, hence a CVC structure. Clearly in all the forms in (6) the misproduced syllables are heavy. It should be noted that each misarticulated syllable is realized as long $/ \mathrm{m}: /$. In fact, the duration of [m:] in (6) is approximately twice as long as that of $[\mathrm{m}]$ in (1), the former ranging from $420 \mathrm{~ms}$ to $500 \mathrm{~ms}$ and the latter from $200 \mathrm{~ms}$ to $220 \mathrm{~ms}^{4}{ }^{4}$ Therefore, this distinction in segmental length should reflect the moraic difference between light and heavy syllables in the target forms. Put differently, the weight distinction in the target is preserved in the phonetic form even though it may be misproduced. The onset of a target, however, may not be realized in such forms as [tan.m:.bi], [m:.tfi.es], and [ku.re.m:]. Note that in Japanese the onset does not bear a mora itself and does not play a role as a weight unit. It should be emphasized here that the prosodic information of the target, at least partially, is likely to be preserved

4 In the present study, the misarticulation is analyzed purely from a phonological perspective. We do not go into the acoustic details any further. 
in misarticulated forms, which clinicians should not overlook because it may serve as a valuable key to detect the misarticulator's underlying phonological knowledge.

\section{REPRESENTATION OF /o/ AND /m/}

In this section, we make a rather in-depth and detailed inquiry into the child's phonological system. Specifically, the emphasis is placed on why the target /o/ should be replaced by a drastically different segment of bilabial nasal $/ \mathrm{m} /$. First let us review the phonological features of these two segments. Below in (7), the feature specifications of $/ \mathrm{o} /$ and $/ \mathrm{m} /$ are presented. (Not all features are shown.)

(7) Feature specification of $/ \mathrm{o} /$ and $/ \mathrm{m} /$

/o/: [+sonorant, -consonantal, -high, -low, +back, +round, ...]

$/ \mathrm{m} /$ : [+sonorant, +consonantal, -continuant, +nasal, Labial ...]

Here, two features attract our attention: they are [+round] for /o/, and [Labial] for /m/. Although the feature [round] denotes lip-rounding of vowels and consonants and [Labial] is classified as a place-of-articulation feature, it is evident that they are closely related to each other because both are pertinent to the "lips". Spencer (1996) defines [Labial] as "a unary feature. Sounds marked with this feature involve a constriction of the lips to give either a labial (labiodental) consonant or a rounded vowel/glide." Let us examine the relationship between the two features in the hierarchical organization of the distinctive feature system. In traditional articulation-oriented versions of feature geometry, [Labial] is a controller of [round] and [round] is a dependent of [Labial] as in (8). ${ }^{5}$

(8) Relationship between [Labial] and [round]

Labial

[round]

This representation implies that if a segment is specified as [+round], then it necessarily must be [Labial] (but not vice versa). Therefore, /o/ is redundantly specified as [Labial] because it is specified as [+round]. Then, /o/ and / $/ \mathrm{m} /$ share "labiality."

The relationship between the two features is more straightforward in other types of feature geometry. For example, consider the geometric representation which allows full integration between vowels and consonants, as the one proposed in Lahiri and Evers (1991). They postulate a node named "Articulators" attached to the PLACE node, which consists of [Labial], [Coronal] and [Dorsal] as in generic types of geometry. However, each articulator dominates both consonants and vowels. [Labial] governs labial consonants and rounded vowels. Thus, this type of geometry allows full interaction between /o/ and $/ \mathrm{m} /$. Still in another type of feature geometry called the Unified Feature Theory proposed by 0dden (1991), Clements and Hume (1995), and Hume (1996) which departs

5 For some proposals of this generic type, see Sagey 1986 and Halle 1995. 
rather radically from the articulation-oriented model, rounding of vowels is equivalent to the labiality of consonants, which makes the distance between $/ \mathrm{o} /$ and $/ \mathrm{m} /$ much closer (Uffmann 2011). We can conclude this section by arguing that the representations of $/ \mathrm{o} /$ and $/ \mathrm{m} /$ are interrelated with each other by the feature [Labial], even though the proposed models differ in their theoretical implications.

\section{PHONOLOGICAL ANALYSIS}

Assuming that a close interconnection exists between $/ \mathrm{o} /$ and $/ \mathrm{m} /$ in terms of the feature [Labial], why is the target $/ \mathrm{o} /$ replaced by $/ \mathrm{m} /$ ? After all, the former is a vowel, while the latter is a consonant and the great difference in phonetic characteristics is still indisputable and should not be overlooked. In this section we discuss this problem from an Optimality-Theoretic perspective.

There are some features which differentiate $/ \mathrm{o} / \mathrm{from} / \mathrm{m} /$ as we have seen in (7). However, what draws a sharp line between these two segments is consonantality; $/ \mathrm{o} /$ is specified as [-consonantal], whereas $/ \mathrm{m} /$ is [+consonantal]. Now, let us posit a faithfulness constraint which urges the input /o/ specified as [-consonantal] to surface in the output. We will call it "Faith (consonantal)." Oppositely, we can posit a markedness constraint "*Labial vowel" which militates against the realization of a labial vowel. Given the evidence of substitution, the marked constraint *Labial vowel outranks the faithfulness constraint Faith (consonantal) in the child's phonological system as in (9).

(9) Constraint ranking

*Labial vowel >> Faith (consonantal)

The replacement of /o/ by [m] in the first form in (1) is illustrated below by the tableau in (10), which basically takes care of the other misproduced forms in (1) and (6).

(10) Tableau for the substitution of /o/ by [m] in / to.ra/

\begin{tabular}{|c|c|c|}
\hline Candidates & *Labial vowel & Faith (consonantal) \\
\hline tm.ra & & $*$ \\
\hline to.ra & $* !$ & \\
\hline
\end{tabular}

\section{DISCUSSION}

The constraint ranking in (9) yields an interesting outcome. First, not only does it induce segmentally deviant forms, but it also results in a syllable nucleus filled by a nasal consonant, which is not normally permitted in the Japanese phonological system. The second and a related point is that it triggers $C(C$ sequences which are also not allowed in Japanese. See examples like [tm] in [tm.ra] and [ni.ua.tm.ri], and [km] in [ta.km] in 
(1). This prosodic or phonotactic violation renders the child's system as deviating from that of adults or normally-developing children. Put differently, respecting * Labial vowel which is ranked lower in the normal system victimizes these important constraints which are observed in Japanese phonology. Let us call the two constraints *Consonant nucleus and *Tautosyllabic CC respectively as in (11).

\section{(11) Two prosodic/phonotactic constraints}

*Consonant nucleus: A syllable nucleus filled by a consonant is disallowed.

*Tautosyllabic CC: A sequence of two consonants within a syllable is banned.

Presented in (12) below is a tableau which includes these two constraints.

(12) A more detailed tableau for the substitution of $/ \mathrm{o} / \mathrm{by} / \mathrm{m} / \mathrm{in} /$ to.ra/

\begin{tabular}{|c|c|c|c|c|}
\hline Candidates & *Labial vowel & $\begin{array}{c}\text { Faith } \\
\text { (consonantal) }\end{array}$ & $\begin{array}{c}* \text { Consonant } \\
\text { nucleus }\end{array}$ & $\begin{array}{c}* \text { Tautosyllabic } \\
\text { CC }\end{array}$ \\
\hline tm.ra & & $*$ & $*$ & $*$ \\
\hline to.ra & $* !$ & & & \\
\hline
\end{tabular}

To summarize, this child retains the * Labial vowel, which is tantamount to saying that he cannot produce a rounded vowel in the back, mid region of the vowel space. However, roundedness is a redundant property in this case because /o/ has no contrasting unrounded counterpart. Therefore the child could have opted to substitute $/ \mathrm{o} /$ with unrounded $/ \gamma /$ without violating the above three constraints. If so, he would sacrifice labiality of the vowel alone, which would result in the child system appearing much more normal. The cause of this apparently idiosyncratic misarticulation, then, can be reduced to only one irregular constraint incidentally ranked higher at one point of acquisition but "stubbornly refusing to demote" in the child's phonological system when the system is supposed to develop. It should be pointed out that the nature of misarticulation has to do with which alternative the child selects when the target is not available. Besides counting on the bilabial nasal, there are other ways to retain labiality. For example, bilabial plosives, both voice and voiceless, and the voiceless bilabial fricative are possible alternatives. However, the fact that the child did not choose either of these alternatives suggests that he is choosing the closest segment in feature specification not realizing the specification [-consonantal]. The voiceless bilabial plosive [p] and the fricative $[\phi]$ would be specified to the contrary in sonorance and voicing and the voiced plosive $[\mathrm{b}]$ again in sonorance. In a sense the child is faithful to the input specifications except that he sacrifices the proper specification in consonantality.

Finally, it is discussed that this case should be a focus of attention all the more because Stemberger (2007) discusses a similar case in English. Based on his previous work (Stemberger, Berhardt and Johnson 1999), he introduces a child who produces the following forms. 
(13) A case presented in Stemberger (2007)

$\begin{array}{lll}\text { Phonetic forms } & \text { Target forms } & \text { Gloss } \\ \text { [bwək] } & \text { [buk] } & \text { book } \\ \text { [nช:m] } & \text { [nov] } & \text { No }\end{array}$

In this case also, the child cannot produce the back, rounded vowels. What this child does is to compensate for it by adding a rounded glide or nasal around the nucleus. Stemberger (2007) claims that in most dialects of English, the rounding of vowels is not very important, because there are no unrounded counterparts; adult speakers routinely reduce rounding to almost nothing when smiling, with no effects on intelligibility, but that children who have no rounded vowels shift labiality off the vowel in ways that impact negatively on intelligibility (Stemberger 2007:48). The child retains labiality at the sacrifice of the target syllable structure; the retention of labiality results in creating a complex onset in the first form and a coda in the second where they should not be. The misarticulation in (13) is another case in which deviant forms are caused by preserving an unusual feature specification. This case suggests that the persistance of such irregular specifications in phonological development is cross-linguistically one common source of functional speech disorders. Lastly, it should be noted that some such cases would be clinically confusing without the phonological underpinnings discussed here.

\section{CONCLUSION}

In this study, we have discussed the phonological system of a child who replaces the target /o/ with [m] owing to a constraint which prohibits the phonetic property of labiality to surface in a vowel. It is indeed a very rare case but the real idiosyncrasy may not be the substitution pattern itself, but the way the irregular feature specification is retained. Though the labiality or roundedness of $/ \mathrm{o} /$ is a redundant feature in Japanese in terms of intelligibility, it is nonetheless retained at the sacrifice of vowel/ consonant distinction. This conclusion is arrived at as a natural consequence of constraint-based phonological analysis with hierarchical organization of the feature system. It is also suggested that retention of non-adult-like feature specifications is cross-linguistically a common underlying source of functional misarticulation and that the resulting production can be clinically confusing.

\section{REFERENCES}

Clements, G. N. and E. Hume. 1995. The internal organization of speech sound. In J. A. Goldsmith (ed.) The Handbook of Phonological Theory. Cambridge, Mass. \& 0xford: Blackwell, 245-306.

Hall, T. A. 2007. Segmental features. In P. de Lacy (ed.) The Cambridge Handbook of Phonology. Cambridge: CUP, 317-334.

Halle, M. 1995. Feature geometry and feature spreading. Linguistic Inquiry 26, 1-46. Homma,S.2000.Kinousei-koon-shogai(Functional Speech Disorders). Tokyo:Kenpakusha. 
Hume, E. 1996. Coronal consonant, front vowel parallels in Maltese. Natural Language and Linguistic Theory 14, 163-203.

Ito, K. 1990. Kodomo-no Kotoba (Child Language). Tokyo: Keiso-shobo.

Lahiri, A. and V. Evers. 1991. Palatalization and coronality. In C. Praradis and J. F. Prunet (eds.) Phonetics and Phonology, Vol. 2; The Special Status of Coronal: Internal and External Evidence. San Diego: Academic Press, 79-100.

Odden, D. 1991. Vowel geometry. Phonology 8, 261-289.

Prince, A. \& P. Smolensky. 2004. Optimality Theory: Constraint Interaction in Generative Grammar. Cambridge, Mass. \& 0xford: Blackwell.

Sagey, E. 1986. The representation of relations in nonlinear phonology. Unpublished Ph.D. dissertation, MIT.

Spencer, A. 1996. Phonology. Cambridge, Mass. \& Oxford: Blackwell.

Stemberger, J. P. 2007. Linguistic foundations of speech production. In S. McLeod (ed.) The International Guide to Speech Acquisition. New York: Thomson Delmar Learning, 44-54.

Stemberger, J. P., B. H. Bernhardt and C. E. Johnson. 1999. "Regressions" ("u-shaped learning") in the acquisition of prosodic structure. Presented at the $6^{\text {th }}$ International Child Language Congress. Trieste.

Uffmann, C. 2011. The organization of features. In M. Oostendorp, C. J. Ewen, E. Hume and K. Rice (eds.) The Blackwell Companion to Phonology I. Cambridge, Mass. \& 0xford: Blackwell, 643-668.

\section{SUMMARY}

\section{RETENTION OF AN IRREGULAR FEATURE SPECIFICATION AS A SOURCE OF FUNCTIONAL MISARTICULATION}

The present study attempts to analyze the phonological system of a Japanesespeaking child with a very idiosyncratic functional (non-organic) speech disorder, wherein a target back rounded vowel is always replaced by a bilabial nasal. First, I examine the feature specifications of the two segments and argue that they share a phonological feature [Labial] in the hierarchical organization of distinctive features. Focusing on the substitution pattern and its theoretical consequence under Optimality Theory, I then discuss that in the child's system a markedness constraint which prohibits a labial vowel outranks opposing faithfulness constraints, resulting in the appearance of the target vowel being replaced by the labial nasal; the substitution is triggered by wrong specifications of the related features. I further argue that the constraint ranking results in creating illegitimate prosodic structures, as well as misproduction of the target segment per se. Finally, it is suggested that the retention of such irregular feature specifications in phonological development is common across languages and that it can be a source of functional misarticulation.

KEYWORDS: phonological development, speech disorder, functional misarticulation, feature geometry, 0ptimality Theory. 


\section{ACKNOWLEDGEMENTS}

An earlier version of this paper was presented at the $13^{\text {th }}$ Meeting of the International Clinical Linguistics and Phonetics Association in 0slo, Norway, in 2010. I am grateful to Martin Ball, Sara Howard, and Sharynne McLeod for their comments on the earlier version. I also wish to thank Biljana Čubrović, Stuart Davis and Hiroko Saito for their detailed comments and helpful suggestions. Any shortcomings are mine alone. This work was supported in part by grants-in-aid from Japan Society for the Promotion of Science (20520353, 23320083 and 24320087), whose support is hereby gratefully acknowledged.

(Original scientific paper received 09.12.2013; revised 23.12.2013; accepted 25.12.2013) 